\title{
Обмін досвідом
}

УДК 616.718.72-07-089

DOI:10.24061/2413-0737/XXI.2.82.2.2017.86

\section{М.В. Гасько, П.С.Ковальчук, А.Т. Зінченко, С.В. Тулюлюк, Ю.М. Падиніч *, Д.М. Гасько** НАШ ДОСВІД ХІРУРГІЧНОГО ЛІКУВАННЯ ХВОРИХ З ПЕРЕЛОМАМИ П'ЯТКОВОЇ КІСТКИ}

Вищий державний навчальний заклад України «Буковинський державний медичний університет», м. Чернівці *Обласна комунальна установа «Лікарня швидкої медичної допомоги», м. Чернівці

** Центр травматології та ортопедії «Angelholm», м. Чернівці

Резюме. У статті наводиться аналіз результатів лікування 45 пацієнтів із переломами п'яткових кісток. 3 метою вивчення ефективності лікування осіб із переломами п'яткових кісток усі пацієнти були розподілені на три клінічні групи.

До першої групи увійшли 12 (26,60 \%) пацієнтів із позасуглобовими переломами п'яткових кісток, яким проводилось оперативне втручання 3 використанням гвинтів та дротяної петлі.

Друга група представлена 19 (42,30 \%) пацієнтами, із внутрішньосуглобовими переломами п'яткових кісток, яким виконувалася закрита репозиція під ЕОПконтролем та фіксація спицями.

До третьої групи ввійшли 14 (31,10 \%) пацієнтів із внутрішньосуглобовими переломами п'яткових кісток, яким проводилася відкрита репозиція та остеосинтез пластинами та гвинтами.
У 4 (28,6 \%) пацієнтів у післяопераційному періоді спостерігалися некрози шкіри, у 3 (21,4 \%) пацієнтів виник деформівний артроз підтаранного суглоба з вираженим больовим синдромом та порушенням ходи, i тільки в 7 (50,0 \%) осіб отримані добрі результати лікування - 79 балів за шкалою AOFAS.

Таким чином, аналіз віддалених результатів оперативного лікування внутрішньосуглобових переломів п'яткової кістки показав, що застосування закритої репозиції під ЕОП-контролем та фіксації спицями призводить до покращення результатів лікування та зменшення термінів непрацездатності.

Ключові слова: перелом п'яткової кістки, малоінвазивний остеосинтез, накістковий остеосинтез, наслідки переломів п'яткової кістки.
Вступ. Відомо, що переломи п'яткових кісток призводять до анатомічних змін і порушень біомеханіки руху. Але за останні роки в літературі мало висвітлюється проблема таких пошкоджень. Стопа втрачає нормальну адаптаційну функцію стояння та ходи, що призводить до тривалих функціональних розладів та інвалідності $[1,4]$.

Серед кісток заплесна найчастіше трапляються переломи п'яткової кістки. У структурі переломів опорно-рухового апарата, за даними різних авторів, їх частка становить від $2 \%$ до $6 \%$ та 60 \% від переломів заплесна [3, 7]. Незважаючи на це, серед ортопедів-травматологів не сформувалось єдиного підходу до класифікації, діагностики та лікування переломів п'яткової кістки. Залежно від механізму травми переломи п'яткової кістки розподіляють на два основні види: позасуглобові - 25 \% від усіх переломів та внутрішньосуглобові - $75 \%[2,7]$.

Найбільша кількість ускладнень виникає після внутрішньосуглобових переломів. Післятравматична деформація підтаранного суглоба призводить до деформівного артрозу, компресійного теносиновіїту сухожилків малогомілкових м'язів, трофічних змін м'яких тканин $[1,6]$.

За даними літератури, консервативне лікування внутрішньосуглобових переломів зі зміщенням відламків у 69-90 \% випадків призводить до незадовільних результатів [5, 6]. Перевагу при внутрішньосуглобових переломах надають хірургічним методам лікування - відкрита репозиція суглобових фасеток, відновлення фізіологічної анатомії п'яткової кістки та стабільна фіксація.

Більшість ортопедів-травматологів для відкритої репозиції та стабільної фіксації відламків застосовують L-подібний хірургічний доступ. Такий травматичний хірургічний доступ часто призводить до некрозів шкіри, нейросудинних порушень, післяопераційного компартментсиндрому, виникнення остеомієліту, пошкодження сухожилків перонеальної групи $[1,3]$. Кількість незадовільних результатів лікування внутрішньосуглобових переломів п'яткової кістки досягає до $34 \%[1,5]$. У зв'язку з цим триває пошук більш ефективних малоінвазивних методів оперативного лікування переломів п'яткової кістки.

Мета дослідження. Розробити оптимальну тактику хірургічного лікування переломів п'яткової кістки.

Матеріал і методи. За період з 2011 по 2016 pp. у травматологічному відділенні ОКУ «Лікарня швидкої медичної допомоги» (ЛШМД) м. Чернівці проліковано 45 пацієнтів із переломами п'яткових кісток, яким проводилось оперативне втручання. 3 метою вивчення ефективності лікування осіб із переломами п'яткових кісток усі пацієнти були розподілені на три клінічні групи.

До першої групи увійшли 12 (26,60 \%) осіб iз позасуглобовими переломами п'яткових кісток, яким проводилось оперативне втручання з використанням гвинтів та дротяної петлі.

Друга група представлена 19 (42,30 \%) пацієнтами, із внутрішньосуглобовими переломами єнтами, із внутрішнь
М. Падиніч, Д.М. Гасько, 2017 
п'яткових кісток, яким виконувалася закрита репозиція під ЕОП-контролем та фіксація спицями.

До третьої групи ввійшли 14 (31,10\%) пацієнтів із внутрішньосуглобовими переломами п’яткових кісток, яким проводилася відкрита репозиція та остеосинтез пластинами та гвинтами.

Середній вік пацієнтів становив 34,4 року і коливався від 19 до 62 років. Більшість із них чоловіки - 39 (86,60 \%), причому основну частину становили чоловіки працездатного віку - 34 (75,50 \%) пацієнти. Аналіз причин переломів п'яткових кісток показав, що в більшості випадків травма зумовлена падінням із висоти - $38(84,40$ \%) та дорожньо-транспортними пригодами - 7 $(15,60 \%)$ пацієнтів.

У всіх клінічних групах лікування хворих розпочинали із протинабрякової терапії, підвищеного положення нижньої кінцівки та лікування супутніх захворювань, а оперативні втручання проводилися на 9-11-ту добу після госпіталізації. Критеріями вибору способу остеосинтезу були вік пацієнта, наявність супутніх захворювань, наявність фліктен, кількість внутрішньосуглобових фрагментів за класифікацією Sanders.

У пацієнтів першої клінічної групи, у більшості випадків, мали місце переломи горба п'яткової кістки 3 малим або великим відірваним уламком. Лікування таких хворих проводили методом закритої або відкритої репозиції та фіксації уламка двома гвинтами, спицями та 8-подібною дротяною петлею. У післяопераційному періоді проводили іммобілізацію кінцівки гіпсовою лонгетою до зняття швів, після чого розпочинали активні та пасивні рухи в гомілковостопному суглобі. Дозоване навантаження на кінцівку дозволяли через 8 тижнів, повне через - 10-12 тижнів.

Хворим 2-ї клінічної групи під ЕОПконтролем проводили закриту репозицію перелому та фіксацію спицями. У післяопераційному періоді гіпсової лонгети не застосовували. Через шість тижнів, після видалення спиць, розпочинали рухи в суглобах стопи, повне навантаження на кінцівку дозволяли з 12-го тижня.

У пацієнтів третьої групи із внутрішньосуглобовими переломами проводили відкриту репозицію та стабілізацію переломів накістковими пластинами. Після оперативного втручання протягом трьох діб кінцівка знаходилась на шині Беллера, хворому призначали знеболювальну терапію, антибіотики, протинабрякову терапію, іммобілізацію кінцівки гіпсовою лонгетою до зняття швів. Ходьбу на милицях дозволяли з 4-го дня після операції, дозоване навантаження на кінцівку розпочинали з 8-го тижня, а повне - 3 12-го тижня.

Результати дослідження та їх обговорення. Віддалені результати лікування вивчені за період від шести місяців до двох років після оперативного втручання. Результати лікування оцінювались за Американською шкалою AOFAS.

Iз 12 пацієнтів першої групи віддалені результати показали, що в 10 (83,3 \%) осіб резуль- тати лікування. оцінювались як добрі (80 балів за шкалою AOFAS). У 2 (16,7 \%) пацієнтів, у ранньому післяопераційному періоді спостерігали нагноєння м'яких тканин, яке було своєчасно ліквідовано впродовж 10 днів і не вплинуло на результати лікування.

У 19 осіб другої клінічної групи, яким застосовувалася закрита репозиція внутрішньосуглобових переломів та фіксація спицями, ранніх післяопераційних ускладнень не спостерігали. У 16 $(84,2 \%)$ пацієнтів отримані добрі результати лікування (74 бали за шкалою AOFAS). Тільки у 3 $(15,8 \%)$ осіб через 1-2 роки виник деформівний артроз із больовим синдромом (58 балів).

Із 14 пацієнтів третьої клінічної групи в 4 (28,6 \%) осіб у післяопераційному періоді спостерігали некрози шкіри, у 3 (21,4 \%) - настав деформівний артроз підтаранного суглоба 3 вираженим больовим синдромом та порушенням ходи, і тільки в 7 (50,0 \%) пацієнтів отримані добрі результати лікування - 79 балів за шкалою AOFAS.

Таким чином, аналіз віддалених результатів оперативного лікування внутрішньосуглобових переломів п'яткової кістки показав, що застосування закритої репозиції під ЕОП-контролем та фіксації спицями призводить до покращення результатів лікування та зменшення термінів непрацездатності.

\section{Висновки}

1. Вибір способу остеосинтезу п'яткової кістки повинен базуватися на даних загального стану пацієнта, характеру перелому та соціальними потребами хворого.

2. Закрита репозиція під контролем за допомогою електронно-оптичного перетворювача та фіксація спицями дозволяє зменшити травматичність оперативних втручань та ризик гнійних ускладнень.

3. Віддалені результати лікування хворих із внутрішньосуглобовими переломами п’яткової кістки показали, що закрита репозиція і фіксація переломів спицями призводить до кращих результатів лікування 84,2 \% випадків, порівняно 3 накістковим остеосинтезом - $50 \%$.

\section{Література}

1. Лябах А.П. Ускладнення після переломів п'яткової кістки та їх хірургічне лікування / А.П. Лябах// Вісн. ортопедії, травматол. та протез. -2000. - № 72 (27). C. 17-19.

2. Нанинець В.Я. Диференційна діагностика больового синдрому в задньому відділі стопи у пацієнтів із неправильно зрощеними переломами п'яткової кістки / В.Я. Нанинець, А.П. Лябах // Вісн. ортопедії, травматол. та протез. - 2016. - № 2 (89). - С. 58-59.

3. Нікітін П.В. Діагностика та лікування пошкоджень кісток стопи/ Нікітін П.В. - К., 2005. - 188 с.

4. Рябоконь П.В. Остеосинтез внутрішньосуглобових переломів п’яткової кістки блокованим стрижнем: автореф. дис. на здобуття наукового ступеня канд. мед. наук. - К., 2016. - 19 с.

5. Surgical versus nonsargical treatment of displaced intraarticular fracture: a meta-analisis of current evidence base N. Jiang, Q. Lin, X. Diao [et al.] // Internat. Orthop. Assoc. - 2012. - Vol. 36, № 8. - P. 1615-1622. 
6. Subtalar versus triple arthrodesis after intra-articular calcaneal fractures / T. Scheper, B.C.T. Kieboom, G.H.J.M. Bessems [et al.] // Strat. Traum. Limb. Rec. 2010. - Vol. 5, № 1. - P. 97-103.
7. Operative treatment in 120 intra-articular calcaneal fractures: Results using a prognostic tomography scan classification / R. Sanders, P. Fortin, T. DiPasquale T. [et al.] // Clin. Orthop. - 1993. - Vol. 290. - P. 87-95.

\section{НАШ ОПЫТ ХИРУРГИЧЕСКОГО ЛЕЧЕНИЯ ПАЦИЕНТОВ С ПЕРЕЛОМАМИ ПЯТОЧНОЙ КОСТИ}

\section{М.В. Гасько, П.Е. Ковальчук, А.Т. Зинченко, С.В. Тулюлюк, Ю.М. Падинич *, Д.М. Гасько**}

Резюме. В статье приводится анализ результатов лечения 45 больных с переломами пяточных костей. С целью изучения эффективности лечения больные с переломами пяточных костей были разделены на три клинические группы.

Первую группу составили 12 (26,60 \%) больных с внесуставными переломами пяточных костей, которым проводилось оперативное вмешательство с использованием винтов и проволочной петли.

Вторая группа представлена 19 (42,30 \%) больных, с внутрисуставными переломами пяточных костей, которым выполнялась закрытая репозиция под ЭОП-контролем и фиксация спицами.

В третью группу вошли 14 (31,10 \%) больных с внутрисуставными переломами пяточных костей, которым проводилась открытая репозиция и остеосинтез пластинами и винтами.

У 4 (28,6 \%) больных в послеоперационном периоде наблюдались некрозы кожи, у 3 (21,4\%) больных наступил деформирующий артроз подтаранного сустава с выраженным болевым синдромом и нарушением походки и только в 7 (50,0 \%) больных получены хорошие результаты лечения - 79 баллов по шкале AOFAS.

Таким образом, анализ отдаленных результатов оперативного лечения внутрисуставных переломов пяточной кости показал, что применение закрытой репозиции под ЭОП-контролем и фиксации спицами приводит к улучшению результатов лечения и уменьшения сроков нетрудоспособности.

Ключевые слова: перелом пяточной кости, малоинвазивный остеосинтез, накостный остеосинтез, последствия переломов пяточной кости.

\section{OUR EXPERIENCE OF SURGICAL TREATMENT OF PATIENTS WITH FRACTURES OF THE CALCANEUS}

\section{M.V. Hasko, P.Ye.Kovalchuk, A.T. Zinchenko, S.V. Tuliuliuk, Yu.M. Padynych *, D.M. Hasko **}

Abstract. The article analyzes the results of treating 45 patients with fractures of the calcaneus. To study the effectiveness of the treatment of patients with fractures of the heel bone, all patients were divided into three clinical groups.

The first group consisted of $12(26,60 \%)$ patients with extra-articular fractures of the calcaneus, which were carried out surgery using screws and a wire loop.

The second group was represented by 19 (42,30\%) patients with intra-articular fractures of the calcaneus, who underwent closed reduction under image intensifier control and locking the spokes.

The third group included $14(31,10 \%)$ patients with intra-articular fractures of the calcaneus, which had an open reduction and osteosynthesis with plates and screws.

In $4(28,6 \%)$ patients in the postoperative period there were skin necrosis, $3(21,4 \%)$ patients came deforming arthrosis of the subtalar joint with severe pain and impaired gait and only $7(50,0 \%)$ patients with good results treatment -79 points on the AOFAS scale.

Thus, the analysis of the long-term results of surgical treatment of intra-articular fractures of the calcaneus has shown that the use of closed reduction under image intensifier control and locking the spokes leads to better treatment results and reducing the time of disability. fractures.

Key words: calcaneus fracture, minimally invasive osteosynthesis, bone osteosynthesis, consequences of calcaneus

Higher State Educational Institution of Ukraine «Bukovinian State Medical University» (Chernivtsi) * Regional municipal institution «Emergency Rescue Municipal Hospital» (Chernivtsi) ** Center of Traumatology and Orthopedics «Angelholm» (Chernivtsi)

Рецензент - проф. В.П. Польовий

Buk. Med. Herald. - 2017. - Vol. 21, № 2 (82), part 2. - P. 173-175

Надійшла до редакції 04.04.2017 року

() М.В. Гасько, П.Є.Ковальчук, А.Т. Зінченко, С.В. Тулюлюк, Ю.М. Падиніч, Д.М. Гасько, 2017 